\title{
Performance Evaluation Of Bacterial Consortium For Biodegradation Of Total Petroleum Hydrocarbon: A Comparative Strategic Biostimulation Study
}

Ipsita Dipamitra Behera ( $\boldsymbol{\nabla}$ ipsitadbehera@iitkgp.ac.in )

Indian Institute of Technology Kharagpur

Bhim Charan Meikap

Indian Institute of Technology Kharagpur

Ramkrishna Sen

Indian Institute of Technology Kharagpur

\section{Research Article}

Keywords: Petroleum sludge, Total petroleum hydrocarbon (TPH), Bacterial consortium, Biodegradation, Amendment.

Posted Date: February 10th, 2022

DOI: https://doi.org/10.21203/rs.3.rs-1227394/v1

License: (c) (1) This work is licensed under a Creative Commons Attribution 4.0 International License.

Read Full License 
1 Performance evaluation of bacterial consortium for biodegradation of total petroleum hydrocarbon: A comparative strategic biostimulation study

$19 *$ Corresponding author. Department Chemical Engineering, Indian Institute of Technology Kharagpur, West Bengal - 721302, India

21 E-mail addresses: ipsitadbehera@iitkgp.ac.in; ipsitadbehera@ gmail.com (I.D Behera). 


\section{Abstract}

23 This research work demonstrated the comparative study of the efficacy of poultry litter extract (PLE) and 24 inorganic fertilizer (NPK) as biostimulating agents for enhancing total petroleum hydrocarbon (TPH) degradation of petroleum refinery sludge (PRS) with bioaugmentation of an indigenously developed bacterial consortium. In this study, six sets of treatments such as natural attenuation, bioaugmentation with the indigenously developed bacterial consortium, and various biostimulation strategies with (MSM100, PLE100, NPK100, MSM50+PLE50, and MSM50+NPK50) were performed to meet 100\% nutrient source for bacterial growth to enhance TPH degradation. Among all, the combined sources of MSM50+PLE50 showed the best performance by degrading the TPH up to $91.3 \pm 4.1 \%$ within $28 \mathrm{~d}$ of the incubation period. The GC-FID analysis confirmed the efficacy of TPH degradation of PRS when PLE amendment with MSM. Further, the removal of maltene and asphaltene was also achieved $92 \pm 3.7 \%$ and $52 \pm 2.2 \%$ during this treatment. TPH degradation fitted to first-order kinetics with a rate constant $0.09 \mathrm{~d}^{-1}$ and half-life period of $7.7 \mathrm{~d}$ for MSM50+PLE50 amendment treatment along with bacterial consortium as bioaugmentation. This study revealed the implementation of the PLE amendment not only preferred as a nutrient source for bacterial growth but also enhanced TPH biodegradation in an eco-friendly strategic way by dropping the practice of inorganic salts.

Keywords Petroleum sludge. Total petroleum hydrocarbon (TPH). Bacterial consortium. Biodegradation. Amendment. 
The rapid evolution in industrial sector has instigated in generation of a huge quantity of pollutants to the environment (Gaur et al. 2021). Amongst these, petroleum hydrocarbon pollutants from the petroleum industries need a special attention due to its carcinogenic and toxic effects towards health and environment. The release of hydrocarbon contaminants during the crude oil processing, extraction and transportation causes a serious environmental concern due to its hazardous nature. A significance amount of oily sludge generates from the petroleum industries in which total petroleum hydrocarbon (TPH) is a major concern. TPH refers to petroleumbased hydrocarbons and composed of complex compounds originate from crude oil and considered to be hazardous towards the human as well as habitats (Almeida et al. 2013; Zeneli et al. 2019; Gaur et al. 2021). An eco-friendly, sustainable, and affordable technique is required for safe disposal of these petroleum hydrocarbon pollutants (Varjani 2017; Suganthi et al. 2018; Koolivand et al. 2019). Till date, a series of physical and chemical treatments have been implemented to achieve this goal, but generation of secondary pollutants and high cost are the major concerns of these methods (Taiwo and Otolorin 2009; Qin et al. 2015; Hu et al. 2017; Sivagami et al. 2019). In this regard, the role of microorganisms plays a major character in the process of biodegradation to achieve the safe disposal of petroleum hydrocarbons (PHCs) (Jasmine et al. 2015; Hamidi et al. 2021).

Biodegradation is defined as the complete removal of pollutants from the environment in presence of living microorganisms (Das et al. 2008; Gaur et al. 2021). But under natural circumstances, the availability of hydrocarbon degraders is not sufficient to achieve the complete degradation of hydrocarbons (Szulc et al. 2014). This results low degradation rate of PHCs. To overcome this issue, bioaugmentation strategy can introduce by addition of selected microbes to the polluted sites. Several studies have been documented the successful degradation of PHCs by involving bioaugmentation strategy (Mishra et al. 2001; Sarkar et al. 2017). In a similar manner, adequate amount of nutrients is required for biomolecule synthesis which boost potential hydrocarbon degradation (Fallgren and Jin 2008). The hydrocarbon degradation has been successful with biostimulation strategy by inorganic nitrogen and phosphorus (Almeida et al. 2013; Sarkar et al. 2016; Zeneli et al. 2019). The combinational approach of bioaugmentation and biostimulation result better biodegradation performance than the individual approaches (Wu et al. 2016; Sarkar et al. 2017).

As PHCs are rich in carbon content, so nitrogen plays a major role among the nutrients. Low-cost chemical fertilizer, organic waste, compost and agro-waste can be use as alternative source of nutrients for 
microbial growth. Till date, use of chemical fertilizer as a nutrient source for microbial growth has been documented for biodegradation of PHCs (Machín-Ramírez et al. 2008). Even so, fertilizers are not sufficient for agronomy for the emergent nations that's why it is necessary to pursuit an inexpensive and environmentally approachable selection to replace the fertilizer as nutrient source for biodegradation of PHCs. In considering to this issue, use of organic wastes (animal manure, compost, biochar, plat residue) for degradation of PHCs has been reported (Medina et al. 2015; Ren et al. 2018a; 2018b; Guo et al. 2020; Olawale et al. 2020). The presence of humic and pulvic substances in animal manures enhance the bioavailability of hydrocarbon for the microbial growth (Ezenne et al. 2014). Till date, use of Poultry waste (PW) as biostimulating agent has been limited for degradation of PHCs. The PW can replace the inorganic nutrients, as it contains high source of N, P and K along with important micronutrients. With the due course of the time, during the biodegradation process, the uric acid and different proteins present in the PW gradually breakdown into nitrogen and phosphorous and easily available by the microorganisms (Fallgren and Jin 2008).

This article focuses on the performance of TPH degradation by the indigenous bacterial consortium with individual/amendment of inorganic chemical fertilizer and poultry litter extract (PLE) in mineral salt media (MSM). The impact of bacterial population was also studied at different nutrient amendments. The GC-FID analysis was conducted to ensure the degradation of TPH in different amendment strategies. Further, the residual TPH were represented in different hydrocarbon fractions (asphaltene and maltene).

\section{Materials and methods}

\section{Materials, chemicals, sample characterization, and media preparation}

In this study, the petroleum refinery sludge (PRS) was collected from Indian oil corporation limited Haldia, West Bengal, India. The PRS sample was stored in a closed container at $4{ }^{\circ} \mathrm{C}$ to avoid volatilization and to avoid any light exposure (Behera et al. 2020). The process of PRS collection and the physicochemical properties of the sample has been reported in the earlier study (Behera et al. 2020). The PW were collected in a ziplock plastic bags from a poultry farm nearby Kharagpur city. The chemical fertilizers such as urea, single super phosphate (SSP), and muriate of potash (MOP) were purchased from agrochemical store from Kharagpur. All the chemicals and solvents (dichloromethane, n-hexane, n-heptane, chloroform, and methanol) used for research work were analytical grade and purchased from Merk India Ltd, Mumbai, India. The PW was oven dried and crushed and passed through $2 \mathrm{~mm}$ sieve to remove the solid particles and stored at $4{ }^{\circ} \mathrm{C}$ for further use. The 
presence of nutrient content, moisture, $\mathrm{pH}$, electrical conductivity was determined as per the standard protocol (manuscript submitted). The $\mathrm{C}, \mathrm{H}, \mathrm{N}$ and $\mathrm{S}$ analysis was performed by CHNS analyzer (ELVario MICRO Cube, Elemental TM) (Table S1).

The MSM used for degradation study composed $\left(\mathrm{g} \mathrm{L}^{-1}\right) \mathrm{KH}_{2} \mathrm{PO}_{4}(0.17), \mathrm{K}_{2} \mathrm{HPO}_{4}(0.435), \mathrm{Na}_{2} \mathrm{HPO}_{4} .7 \mathrm{H}_{2} \mathrm{O}$ (0.668), $\mathrm{NH}_{4} \mathrm{Cl}(0.850), \mathrm{MgSO} 4.7 \mathrm{H}_{2} \mathrm{O}(0.0225), \mathrm{CaCl}_{2} .2 \mathrm{H}_{2} \mathrm{O}$ (0.0275) and $\mathrm{FeCl}_{3}$ (0.00025) (Jasmine and Mukherji 2015). The inorganic fertilizer (NPK) media was prepared by $\left(\mathrm{g} \mathrm{L}^{-1}\right) 0.482,0.960$, and 0.241 for N, P, and $\mathrm{K}$ in the form of urea, SSP, and MOP in distilled water. The poultry litter extract (PLE) was used as a substitute of MSM when used as single source of nutrient. A mixture of dried poultry litter and distilled water $\left(25 \mathrm{~g} \mathrm{~L}^{-1}\right)$ was prepared and sterilized for required media for bacterial growth. Different strategic media were prepared by adding PLE and NPK with MSM for biodegradation study of TPH.

\section{Bacterial inoculum and maintenance}

The hydrocarbon degrading bacterial cultures used in this study were previously isolated from the same PRS sample (Behera et al. 2021). The four indigenous bacterial strains used for consortium are Dietzia lutea IRB191, Dietzia lutea IRB192, Staphylococcus warneri BSM19 and Stenotrophomonas pavanii IRB19 (Behera et al. 2021). Equal volume of individual strains was mixed together at the end of the log phase to get the effective consortium (Behera et al. 2021). The indigenous isolated strains were preserved at $-80{ }^{\circ} \mathrm{C}$ in sterile glycerol solution $(20 \%, \mathrm{v} / \mathrm{v})$. The optimum degradation strategy for efficient hydrocarbon degradation were $\mathrm{pH}$, temperature, and percentage of oily sludge concentration were $7,34{ }^{\circ} \mathrm{C}, 2 \%(\mathrm{w} / \mathrm{v})$ respectively (Behera et al. 2021).

\section{Design of experiment}

124 Laboratory scale TPH degradation experiments were conducted in shake flask study for 28 days. For this, six different strategies (T1-T6) were performed in $250 \mathrm{ml}$ flask. The details of the media composition using (MSM, PLE, and NPK) in six different treatments were described in Table 1. The treatment T1 was considered as control without bioaugmentation of bacterial consortium. in case of T2, T3, and T4 biostimulation was reached via adding MSM, PLE and NPK media respectively. In these cases (T2, T3, and T4), 100\% nutrient source was maintained as single media composition. Whereas in T5 
and T6, biostimulation was performed by combination of two medium (MSM+PLE) and (MSM+NPK) at a ratio 1:1 respectively. In each set of strategy, the bioaugmentation was performed by inoculating $5 \%(\mathrm{v} / \mathrm{v})$ of indigenously developed bacterial consortium. For this study, T1 is consider as control, in which biostimulation via MSM nutrients and no bioaugmentation was performed with indigenous developed consortium. However, $2 \%(w / v)$ of sludge was supplemented as the primary source of carbon and energy in each treatment flask. The initial $\mathrm{pH}$ of each medium was maintained at 7 and incubated at $34{ }^{\circ} \mathrm{C}$ and $120 \mathrm{rpm}$ (Behera et al. 2021).

Table 1

\section{Total hydrocarbon degrading bacteria}

To enumerate the total bacterial population $\left(\mathrm{CFU} \mathrm{mL} \mathrm{m}^{-1}\right)$, in each three days intervals $1 \mathrm{~mL}$ of media subsequently diluted with sterile $\mathrm{NaCl}$ solution $(0.9 \mathrm{w} / \mathrm{v})$. From this proper dilution, $100 \mu \mathrm{L}$ of solution were plated on nutrient agar. The total bacterial population were counted after 12 to $24 \mathrm{~h}$ of incubation at $34{ }^{\circ} \mathrm{C}$ and express in (Ln N).

\section{Residual TPH extraction and analysis}

\section{Hydrocarbon extraction and gravimetric analysis}

The residual TPH present in degradation study, was extracted and quantified gravimetrically at various time intervals $(7 \mathrm{~d}, 14 \mathrm{~d}, 21 \mathrm{~d}$, and $28 \mathrm{~d}$ ) from each treatment strategy. Further, the TPH was fractionated to maltene (soluble in n-heptane) and asphaltene (insoluble in n-heptane) and weighted gravimetrically. The following equation (1) was used to calculate the percentage of TPH degradation gravimetrically.

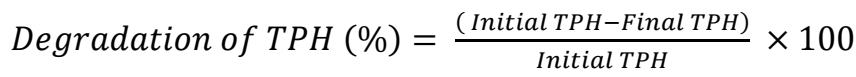

\section{Gas Chromatographic analysis}

The extracted TPH samples were dissolved in dichloromethane and concentrated to a particular volume by evaporation for GC-FID analysis (PerkinElmer GC system/Clarus 480 with flame ionization detector and DB 5, $30 \mathrm{~m} \times 0.32 \mathrm{~mm} \times 0.25 \mu \mathrm{m}$, capillary column). The gas chromatography methodology was followed as per our previous study of total run time for 45 min (Behera et al. 2020).

\section{Kinetic of TPH degradation}


156 Kinetic study is essential to (a) measure the biodegradation speed, (b) to understand biodegradation process.

157 Further, kinetic study exemplifies the existence of residual TPH at any time and future prediction of its 158 occurrence during degradation (Kuppusamy et al. 2016). Mostly the biodegradability of hydrocarbons explains the first-order and second order kinetics.

First-order kinetics:

$C_{t}=C_{i} e^{-k_{1} t}$

$t_{1 / 2}=\frac{\ln _{2}}{k_{1}}=\frac{0.693}{k_{1}}$

Second-order kinetics:

$164 \frac{1}{C_{t}}=k_{2} t+\frac{1}{C_{i}}$

165

$t_{1 / 2}=\frac{1}{k_{2} C_{i}}$

where $C_{i}\left(\mathrm{~g} \mathrm{~kg}^{-1}\right)$ and $C_{t}\left(\mathrm{~g} \mathrm{~kg}^{-1}\right)$ represents the initial $(t=0)$ and final $(t=t)$ TPH concentration respectively, $\left(t_{1 / 2}\right)$ is the time $(\mathrm{d})$ required to reduce the initial TPH concentration by one-half. Whereas $k_{1}\left(\mathrm{~d}^{-1}\right)$ is the firstorder rate constant and $k_{2}\left(\mathrm{~kg}^{-1} \mathrm{~d}^{-1}\right)$ is the second-order rate constant. The rate constant $\left(k_{1}\right.$ and $\left.k_{2}\right)$ were calculated from the slope by plotting $\left(-\ln \frac{C_{t}}{C_{i}}\right)$ and $\frac{1}{C_{t}}$ versus time $(t)$, respectively. The time required to reduce the half of the concentration of TPH during degradation process is known as half-life time $\left(t_{1 / 2}\right)$. It is necessary for environmental fate modelling, chemical screening and alteration of pollutants. The corresponding half-life $\left(t_{1 / 2}\right)$ value were calculated using equation (3) and (5).

\section{Results and discussions}

\section{Total bacterial population}

176 The sample from each treatment were individually analyzed for total bacterial papulation by plate count method 177 at different time $\left(0^{\text {th }}, 3^{\text {rd }}, 6^{\text {th }}, \ldots\right.$ and $28^{\text {th }}$ day $)$ and the result were depicted in Fig. 1 . The increased biomass with 178 the period of time was represented by $\mathrm{CFU} \mathrm{mL} \mathrm{m}^{-1}$ (Fig. 1). The result of this current study displayed maximum populations in the treatments T5. In treatment T5, the bacterial population was increased from $0.97 \pm 0.03 \times 10^{8}$ $\mathrm{CFU} \mathrm{mL} \mathrm{m}^{-1}\left(3^{\text {rd }}\right.$ day) to $2.9 \pm 0.08 \times 10^{8} \mathrm{CFU} \mathrm{mL}^{-1}\left(6^{\text {th }}\right.$ day) and reached the maximum $1.1 \pm 0.28 \times 10^{10} \mathrm{CFU} \mathrm{mL}^{-1}$ 

of incubation then reduced to $2.2 \pm 0.24 \times 10^{9} \mathrm{CFU} \mathrm{mL}^{-1}$ on $28^{\text {th }}$ day. The rapid increased in biomass is due to the combined effort of presence of hydrocarbon of the PRS, MSM, and additional source of nutrients in PLE. Similar type of trends was also observed in different treatments, but the increased biomass varies in different strategies. Next to the PLE and MSM amendment, the PLE100 (T3) showed the total bacterial population reached to maximum $9.5 \pm 0.23 \times 10^{8} \mathrm{CFU} \mathrm{mL} \mathrm{m}^{-1}$ followed by MSM100 (T2) strategy (Fig. 1). In case of Treatment T1(control) the maximum growth was reached up to $1.3 \pm 0.04 \times 10^{8}$. The availability of indigenous culture in treatment $\mathrm{T} 1$ utilized the petroleum hydrocarbons for their microbial activities. The increase number of populations with time confirmed the survival of bacterial consortium and utilization of hydrocarbons as sole source of carbon and energy (Tao et al. 2017). In this study, the used bacterial consortium is indigenous in nature so they can easily adapt to PRS. Increase in microbial population corresponded to increase in TPH degradation observed in this study.

Figure 1

\section{Total Petroleum hydrocarbon degradation}

The TPH degradation percentage was estimated for each treatment in seven days intervals by solvent extraction followed by gravimetric method and represented in Fig. 2. The TPH degradation percentage was increased in each treatment with respect to incubation time which signified that the survival of bacterial consortium in different amendments and utilization of hydrocarbons as their metabolic activities. The highest TPH degradation was noticed for the treatment T5 and the TPH degradation was achieved $91.3 \pm 4.1 \%$ after 28 days of incubation (Fig. 2). However, a substantial amount $(82.55 \pm 3.4 \%)$ of TPH degradation was observed in treatment $\mathrm{T} 2$. Further the percentage of TPH degradation was $78.5 \pm 2.5$ and $62.7 \pm 3.1 \%$ for the treatment $\mathrm{T} 3$ and $\mathrm{T} 4$ respectively. In this study the NPK amendments showed comparatively lower degradation than PLE amendments but higher than the control. This may be due the bioavailability of the nutrients in PLE amendment is more than the NPK amendment for bacterial activities. However, treatment T5 showed the maximum TPH degradation, where both MSM and PLE were supplied (1:1) (Fig. 2). The presence of humic and fulvic substances in the PLE which enhanced the bioavailability of TPH in the medium for bacterial growth and activities (Ezenne et al. 2014). Further, the addition of organic amendments may increase the microbial activities by enhancing the dissolved organic matter in the medium (Rahman et al. 2002; Wei et al. 2014). 

2002; Olawale et al. 2020).

Figure 2

The TPH degradation of the PLE amendment of this study represented the better result than the results obtained previously (Gholami-Shiri et al. 2017; Roy et al. 2018; Jasmine and Mukherji 2019; Zeneli et al. 2019; Hamidi et al. 2021) and a comparative result has represented in Table 2.

The extracted maltene fractions comprised of aliphatic, aromatics and NSO in the range $52 \pm 4 \%, 39 \pm$ $2 \%$, and $9 \pm 1 \%$, respectively (Behera et al. 2020). The heavier asphaltene was found to be $90 \pm 3 \mathrm{~g} \mathrm{~kg}^{-1}$, which is 50\% of TPH in this PRS sample. The degradation of maltene and asphaltene fractions for different amendment strategies has been described in Fig 3. It was noticed that both the maltene and asphaltene fractions reduced in each strategy as compared to control (T1) (Fig. 3). At the end of $28^{\text {th }}$ day, the degradation of maltene was highest $(92 \pm 3.7 \%)$ and asphaltene was found to be $(52 \pm 2.2 \%)$ for T5. Presence of particulate matter along with organic matter in the PRS enhanced the degradation of maltene (Jasmine and Mukherji 2015). The degradation of asphaltene is low due to its complex and recalcitrant in nature (Jasmine and Mukherji 2019). But Reddy at al. (2011) reported the degradation of asphaltenes (26\%) in slurry phase reactor in 10 days.

Figure 3

The samples were withdrawn on completion of 28 days for their degradation study. The residual TPH of all treatments after degradation of 28 days were represented by gas chromatograms obtain from GC-FID analysis (Fig. 4). The presence of TPH in the original PRS sample and its GC-FID chromatogram has been reported in our previous report (Behera et al. 2021). From the Fig. 4, it was confirmed that the TPH degradation comparatively higher in case of T5. This depicted the maximum hydrocarbons were utilized by the microorganisms in T5. The obtained chromatograms providing the evidence of gravimetric result of TPH degradation (Fig. 4). 
236 Kinetic modelling was practiced to evaluate the rate of TPH degradation in the studied systems. The regression 237 analysis data of TPH degradation fitted to both first and second order kinetics. The corresponding $\mathrm{R}^{2}$ value, $k_{l}$, $238 k_{2}$, and half-life period $\left(\mathrm{t}_{1 / 2}\right)$ for individual treatment were summarized in Table 3. For the treatment T5 the TPH 239 degradation fitted to first order kinetics with rate constant $0.09 \mathrm{~d}^{-1}$. The biodegradation rate constant for different strategies were in the range 0.09 to $0.03 \mathrm{~d}^{-1}$. The corresponding half-life period for the treatments (T2, T3, T4,

$241 \mathrm{~T} 5$, and T6) were was found to be in the range 11.4, 17.2, 21, 7.7, and $17.3 \mathrm{~d}$ respectively. Agarry et al. (2010) described the suitability of first-order kinetic model for hydrocarbon degradation. The resulted $\mathrm{R}^{2}$ values of second order kinetics model were higher than those of first order model (Table 3). Therefore, the second orderkinetic described the TPH degradation rate better than the first-order for T1, T2, T3, T4 and T6. Sarkar et al. (2005) in their study effectively described the better fit of second order kinetic model for hydrocarbon degradation. Similarly, Poorsoleman et al. (2020) reported in his study that the TPH degradation fitted to both first and second-order kinetics. The higher degradation constant and lower half-life observed in T5 than other strategy indicating the higher efficiency of TPH degradation.

Table 3

\section{Conclusion}

251 In this current study, the supply of PLE as nutrient amendments minimized the dose of MSM for TPH biodegradation. The nutrient amendment of MSM (50\%) with PLE (50\%) resulted maximum TPH degradation which is approximately 4 times higher than control when augmented with indigenously developed bacterial consortium. However, the TPH degradation was lowest when NPK used as a single source of nutrient supplement but 2.7 times higher than the control. Based on our kinetic study, we recommended the rate of TPH degradation fitted to the first-order kinetic model for PLE amendment with MSM. The combined utilization of PLE as a nutrient source in MSM, enhanced the TPH degradation and reduced the cast-off inorganic salt, as well as valorising the PL waste management for environmental safety.

\section{Declarations}

Ethics approval and consent to participate Not applicable 
The authors declare that they have no known competing financial interests or personal relationships that could have appeared to influence the work reported in this paper.

Funding This work was supported by DST and the grant number (No. DST/TMD(EWO)/OWUIS-2018/RS-18). The author RS has received the research support from DST.

\section{Author's contributions}

Ipsita Dipamitra Behera: Conceptualization, Experimentation, Data curation, writing - original draft, Methodology, validation. Bhim Charan Meikap: Conceptualization, Project administration, Resources, Supervision, Writing - review \& editing. Ramkrishna Sen: Project administration, Funding acquisition, Resources, Supervision, Writing- review \& editing. All authors read and approved the final manuscript.

The authors thankful to Indian Oil Corporation Limited Haldia, West Bengal, India, for providing the petroleum refinery sludge sample. We are grateful to the Department of Biotechnology and Departmental Research facilities of Chemical Engineering, Indian Institute of Technology Kharagpur, for providing necessary facilities for research. RK is thankful to DST for financial supports (No. DST/TMD(EWO)/OWUIS-2018/RS-18).

\section{References}

Agarry SA, Owabor CN, Yusuf RO (2010) Bioremediation of soil artificially contaminated with petroleum

Almeida CMR, Reis I, Couto MN, Bordalo AA, Mucha AP (2013) Potential of the microbial community present in an unimpacted beach sediment to remediate petroleum hydrocarbons. Environ Sci Pollut Res 20:3176- 

https://doi.org/10.1080/10934529.2020.1866924

Behera ID, Nayak M, Biswas S, Sen R, Meikap BC (2021) Enhanced biodegradation of total petroleum hydrocarbons by implementing a novel two-step bioaugmentation strategy using indigenous bacterial consortium. J Environ Manage 292:112746. https://doi.org/10.1016/j.jenvman.2021.112746

Das P, Mukherjee S, Sen R (2008) Improved bioavailability and biodegradation of a model polyaromatic hydrocarbon by a biosurfactant producing bacterium of marine origin. Chemosphere 72:1229-1234. https://doi.org/10.1016/j.chemosphere.2008.05.015

Ezenne GI, Nwoke OA, Ezikpe DE, Obalum SE, Ugwuishiwu BO (2014) Use of poultry droppings for remediation of crude oilpolluted soils: effects of application rate on total and polyaromatic hydrocarbon concentrations. Int Biodeterior Biodegrad 92:57-65. doi:10.1016/j.ibiod.2014.01.025

Fallgren PH, Jin S (2008) Biodegradation of petroleum compounds in soil by a solid-phase circulating bioreactor with poultry manure amendments. J Environ Sci Heal - Part A Toxic/Hazardous Subst Environ Eng 43:125-131. https://doi.org/10.1080/10934520701781202

Gaur VK, Gupta S, Pandey A (2021) Evolution in mitigation approaches for petroleum oil-polluted environment: recent advances and future directions. Environ Sci Pollut Res. 0:1-17. https://doi.org/10.1007/s11356-021-16047-y

Gholami-Shiri J, Mowla D, Dehghani S, Setoodeh P (2017) Exploitation of novel synthetic bacterial consortia for biodegradation of oily-sludge TPH of Iran gas and oil refineries. J Environ Chem Eng 5:2964-2975. https://doi.org/10.1016/j.jece.2017.05.056

Hamidi Y, Ataei SA, Sarrafi A (2021) Biodegradation of total petroleum hydrocarbons in oily sludge: a comparative study of biostimulation, bioaugmentation, and combination of methods. J Chem Technol Biotechnol 96:1302-1307. https://doi.org/10.1002/jctb.6646

Hu J, Gan J, Li J, Luo Y, Wang G, Wu L, Gong Y (2017) Extraction of crude oil from petrochemical sludge: characterization of products using thermogravimetric analysis. Fuel 188:166-172 https://doi.org/10.1016/j.fuel.2016.09.068 
Jasmine J, Mukherji S (2015) Characterization of oily sludge from a refinery and biodegradability assessment using various hydrocarbon degrading strains and reconstituted consortia. J Environ Manage 149:118-125. https://doi.org/10.1016/j.jenvman.2014.10.007

Jasmine J, Mukherji S (2019) Impact of bioremediation strategies on slurry phase treatment of aged oily sludge from a refinery. J Environ Manage 246:625-635. https://doi.org/10.1016/j.jenvman.2019.06.029

Koolivand A, Abtahi H, Parhamfar M, Didehdar M, Saeedi R, Fahimirad S (2019) Biodegradation of high concentrations of petroleum compounds by using indigenous bacteria isolated from petroleum hydrocarbons-rich sludge: efective scale-up from liquid medium to composting process. J Environ Manage 248:109228 https://doi.org/10.1016/j.jenvman.2019.06.129

Kuppusamy S, Thavamani P, Megharaj M, Naidu R (2016) Biodegradation of polycyclic aromatic hydrocarbons (PAHs) by novel bacterial consortia tolerant to diverse physical settings: Assessments in liquid- and slurry-phase systems. Int Biodeter Biodegrad 108:149-157 https://doi.org/10.1016/j.ibiod.2015.12.013

Machín-Ramírez C, Okoh A, Morales D, Mayolo-Deloisa K, Quintero R, Trejo-Hernández M (2008) Slurryphase biodegradation of weathered oily sludge waste. Chemosphere 70:737-744 https://doi.org/10.1016/j.chemosphere.2007.06.017

Medina J, Monreal C, Barea JM, Arriagada C, Fernando B, Cornejo P (2015) Crop residue stabilization and application to agricultural and degraded soils: a review. Waste Manag 42:41-54 https://doi.org/10.1016/j.wasman.2015.04.002

Mishra S, Jyot J, Kuhad RC, Lal B (2001) Evaluation of inoculum addition to stimulate in situ bioremediation of oily-sludgecontaminated soil. App Environ Microbiol 67:1675-1681 https://doi.org/10.1128/AEM.67.4.1675-1681.2001

Guo M, Song W, Tian J (2020) Biochar-facilitated soil remediation: mechanisms and efficacy variations. Front Environ Sci 8:183 https://doi.org/10.3389/fenvs.2020.521512

Olawale O, Obayomi KS, Dahunsi SO, Folarin O (2020) Bioremediation of artificially contaminated soil with petroleum using animal waste:cow and poultry dung. Cogent Eng 7:1-15 https://doi.org/10.1080/23311916.2020.1721409 
Qin L, Han J, He X., Zhan Y, Yu F (2015) Recovery of energy and iron from oily sludge pyrolysis in a fluidized bed reactor. J Environ Manage 154:177-182. https://doi.org/10.1016/j.jenvman.2015.02.030

Rahman KSM, Banat IM, Thahira J, Thayumanavan T, Lakshmanaperumalsamy P (2002) Bioremediation of gasoline contaminated soil by a bacterial consortium amended with poultry litter, coir pith and rhamnolipid biosurfactant. Biores Technol 81:25-32 https://doi.org/10.1016/S0960-8524(01)00105-5

Reddy MV, Devi MP, Chandrasekhar K, Goud RK, Mohan SV (2011) Aerobic remediation of petroleum sludge through soil supplementation: microbial community analysis. J Hazard Mater 197:80-87 https://doi.org/10.1016/j.jhazmat.2011.09.061

Ren X, Zeng G, Tang L, Wang J, Wan J, Liu Y, Yu J, Yi H, Ye S, Deng R (2018a) Sorption, transport and biodegradation-an insight into bioavailability of persistent organic pollutants in soil. Sci Total Environ 610:1154-1163 https://doi.org/10.1016/j.scitotenv.2017.08.089

Ren X, Zeng G, Tang L, Wang J, Wan J, Feng H, Song B, Huang C, Tang X (2018b) Effect of exogenous carbonaceous materials on the bioavailability of organic pollutants and their ecological risks. Soil Biol Biochem 116:70-81 https://doi.org/10.1016/j.soilbio.2017.09.027

Roy A, Dutta A, Pal S, Gupta A, Sarkar J, Chatterjee A, Saha A, Sarkar P, Sar P, Kazy SK (2018) Biostimulation and bioaugmentation of native microbial community accelerated bioremediation of oil refinery sludge. Bioresour Technol 253:22-32 https://doi.org/10.1016/j.biortech.2018.01.004

Sarkar D, Ferguson M, Datta R, Birnbaum S (2005) Bioremediation of petroleum hydrocarbons in contaminated soils: comparison of biosolids addition, carbon supplementation, and monitored natural attenuation. Environ Pollut 136:187-195 https://doi.org/10.1016/j.envpol.2004.09.025

Sarkar J, Kazy SK, Gupta A, Dutta A, Mohapatra B, Roy A, Bera P, Mitra A, Sar P (2016) Biostimulation of indigenous microbial community for bioremediation of petroleum refinery sludge. Front Microbiol 7: 120 https://doi.org/10.3389/fmicb.2016.01407

Sarkar P, Roy A, Pal S, Mohapatra B, Kazy SK, Maiti MK, Sar P (2017) Enrichment and characterization of hydrocarbon-degrading bacteria from petroleum refinery waste as potent bioaugmentation agent for in situ bioremediation. Bioresour Technol 242:15-27. https://doi.org/10.1016/j.biortech.2017.05.010 
Sivagami K, Anand D, Divyapriya G, Nambi I (2019) Treatment of petroleum oil spill sludge using the combined ultrasound and Fenton oxidation process. Ultrasonics Sonochemistry 51:340-349 https://doi.org/10.1016/j.ultsonch.2018.09.007

Suganthi SH, Murshid S, Sriram S, Ramani K (2018) Enhanced biodegradation of hydrocarbons in petroleum tank bottom oil sludge and characterization of biocatalysts and biosurfactants. J Environ Manage 220:8795. https://doi.org/10.1016/j.jenvman.2018.04.120

Szulc A, Ambrożewicz D, Sydow M, Ławniczak Ł, Piotrowska-Cyplik A, Marecik R, Chrzanowski Ł (2014) The influence of bioaugmentation and biosurfactant addition on bioremediation efficiency of diesel-oil contaminated soil: feasibility during field studies. J Environ Manag 132:121-128 https://doi.org/10.1016/j.jenvman.2013.11.006

Taiwo EA, Otolorin JA. (2009) Oil recovery from petroleum sludge by solvent extraction. Petroleum Science and Technology 27:836-44. https://doi.org/10.1080/10916460802455582

Tao K, Liu X, Chen X, Hu X, Cao L, Yuan X (2017) Biodegradation of crude oil by a defined co-culture of indigenous bacterial consortium and exogenous Bacillus subtilis. Bioresour Technol 224:327-332. https://doi.org/10.1016/j.biortech.2016.10.073

Varjani SJ (2017) Microbial degradation of petroleum hydrocarbons. Bioresour Technol 223:277-286. https://doi.org/10.1016/j.biortech.2016.10.037

Wei Z, Zhao X, Zhu C, Xi B, Zhao Y, Yu X (2014) Assessment of humification degree of dissolved organic matter from different composts using fluorescence spectroscopy technology. Chemosphere 95:261-267 https://doi.org/10.1016/j.chemosphere.2013.08.087

Wu M, Dick WA, Li W, Wang X, Yang Q, Wang T, Xu L, Zhang M, Chen L (2016) Bioaugmentation and biostimulation of hydrocarbon degradation and the microbial community in a petroleum-contaminated soil. Int Biodeterior Biodegrad 107:158-164 https://doi.org/10.1016/j.ibiod.2015.11.019

Zeneli A, Kastanaki E, Simantiraki F, Gidarakos E (2019) Monitoring the biodegradation of TPH and PAHs in refinery solid waste by biostimulation and bioaugmentation. J Environ Chem Eng 7:103054 https://doi.org/10.1016/j.jece.2019.103054 
Table 1 Details of various amendments for different treatments.

395 Table 2 Comparison of TPH degradation under different biostimulation strategies between present study and 396 previously reported studies.

397 Table 3 Kinetic study of TPH degradation with different treatments.

Table 1

\begin{tabular}{clcccc}
\hline Treatment No & Amendments & Bioaugmentation & \multicolumn{2}{c}{ Composition (\%) } \\
\hline & & & MSM & PLE & NPK \\
\cline { 3 - 6 } T1 & MSM (control) & No & 100 & 0 & 0 \\
T2 & MSM & Yes & 100 & 0 & 0 \\
T3 & PLE & Yes & 0 & 100 & 0 \\
T4 & NPK & Yes & 0 & 0 & 100 \\
T5 & MSM + PLE & Yes & 50 & 0 & 50 \\
T6 & MSM + NPK & Yes & 50 & 0 & 50 \\
\hline
\end{tabular}

399

400

401

402

403

404

405

406

407 
Table 2

\begin{tabular}{|c|c|c|c|c|}
\hline Consortium & Amendments & $\begin{array}{c}\text { Time of } \\
\text { degradation } \\
\text { (day) }\end{array}$ & $\begin{array}{c}\text { Percentage of } \\
\text { TPH } \\
\text { degradation } \\
\end{array}$ & References \\
\hline Indigenous culture & $\begin{array}{l}\text { Nutrients } \\
\text { (Ammonium nitrate and } \\
\text { monopotassium phosphate) }\end{array}$ & 80 & 52.4 & $\begin{array}{l}\text { Zeneli et al. } \\
\text { (2019) }\end{array}$ \\
\hline $\begin{array}{l}\text { Bacillus cereus BQAR- } \\
\text { O1d, } \\
\text { Bacillus sp. NBRC } \\
\text { 101285, and } \\
\text { Lysinibacillus fusiformis } \\
X-9\end{array}$ & Mineral salt medium & 30 & 52.3 & $\begin{array}{l}\text { Gholami shiri et } \\
\text { al. (2017) }\end{array}$ \\
\hline $\begin{array}{l}\text { Pseudomonas } \\
\text { aeruginosa R7-803, } \\
\text { pseudomonas } \\
\text { fluorescens PSY-11 } \\
\text { Citrobacter, and } \\
\text { amalonaticus SA01 }\end{array}$ & Mineral salt medium & 30 & 35.4 & $\begin{array}{l}\text { Gholami shiri et } \\
\text { al. (2017) }\end{array}$ \\
\hline $\begin{array}{l}\text { Pseudomonas } \\
\text { aeruginosa (RS1), } \\
\text { Microbacterium sp. } \\
\text { (RS2), Bacillus sp. } \\
\text { (RS3), Acinetobacter } \\
\text { bau- mannii (RS4,) and } \\
\text { Stenotrophomonas sp. } \\
\text { (RS5) }\end{array}$ & Nitrate and Phosphopous & 90 & 68.4 & $\begin{array}{l}\text { Jasmine and } \\
\text { Mukherji (2019) }\end{array}$ \\
\hline $\begin{array}{l}\text { Staphylococcus sp. } \\
\text { Al(2011), Rhodococcus } \\
\text { jostii and Arthrobacter } \\
\text { citreus }\end{array}$ & Mineral salt media & 35 & 67.3 & $\begin{array}{l}\text { Hamidi et al. } \\
\text { (2021) }\end{array}$ \\
\hline $\begin{array}{l}\text { Indigenous bacterial } \\
\text { consortium }\end{array}$ & $\begin{array}{l}\text { Nitrate and Phosphate in microcosm } \\
\text { study }\end{array}$ & 120 & $57-75$ & Roy et al. (2018) \\
\hline $\begin{array}{l}\text { Dietzia lutea (IRB191), } \\
\text { Dietzia lutea (IRB192), } \\
\text { Staphylococcus warneri } \\
\text { (BSM19) and } \\
\text { Stenotrophomonas } \\
\text { pavanii (IRB19) }\end{array}$ & MSM with PLE (50:50) & 28 & 91.3 & This study \\
\hline
\end{tabular}


Table 3

\begin{tabular}{cllllll}
\hline Treatment & \multicolumn{3}{l}{ First order kinetics } & \multicolumn{4}{l}{ Second order kinetics } \\
\cline { 2 - 7 } No & $k_{1}\left(\mathrm{~d}^{-1}\right)$ & $t_{1 / 2}(d)$ & $\mathrm{R}^{2}$ & $k_{2}\left(\mathrm{~g} \mathrm{~kg}^{-1} \mathrm{~d}^{-1}\right)$ & $t_{1 / 2}(d)$ & $\mathrm{R}^{2}$ \\
\hline T1 & 0.009 & 77 & 0.92 & 0.00006 & 92.3 & 0.93 \\
T2 & 0.061 & 11.4 & 0.83 & 0.0009 & 6.15 & 0.95 \\
T3 & 0.04 & 17.2 & 0.87 & 0.0007 & 7.9 & 0.98 \\
T4 & 0.033 & 21 & 0.86 & 0.0003 & 18.4 & 0.95 \\
T5 & 0.091 & 7.7 & 0.95 & 0.0023 & 2.4 & 0.93 \\
T6 & 0.04 & 17.3 & 0.87 & 0.0004 & 13.8 & 0.95 \\
\hline
\end{tabular}

416

417

418

419

420

421

422

423

424

425

426

427

428

429

430

431 
433 Figure 1 Total bacterial population ( $\operatorname{Ln} \mathrm{N}$ ) in various treatments such as only MSM without bioaugmentation 434 (T1 as control NA), MSM100 (T2), PLE100 (T3), NPK100 (T4), MSM50+PLE50 (T5), and MSM50+NPK50 435 (T6) during incubation period.

436 Figure 2 Gravimetric analysis of TPH degradation (\%) in different treatments such as only MSM without 437 bioaugmentation (T1 as control NA), MSM100 (T2), PLE100 (T3), NPK100 (T4), MSM50+PLE50 (T5), and 438 MSM50+NPK50 (T6) over the incubation period.

439 Figure 3 Biodegradation of maltene and asphaltene fraction (\%) for different biostimulation strategies after 28 440 days of incubation

441 Figure 4 GC-FID chromatograms were representing the residual hydrocarbon peaks with different treatments 442 after 28 days of incubation. (a) MSM100 without bioaugmentation as control (T1), (b) MSM100, (c) PLE100 (T3), (d) NPK100 (T4), (e) PLE50+MSM50 (T5), and (f) PLE50+NPK50 (T6) with bioaugmentation of 5\% $(\mathrm{v} / \mathrm{v})$ of bacterial consortium.

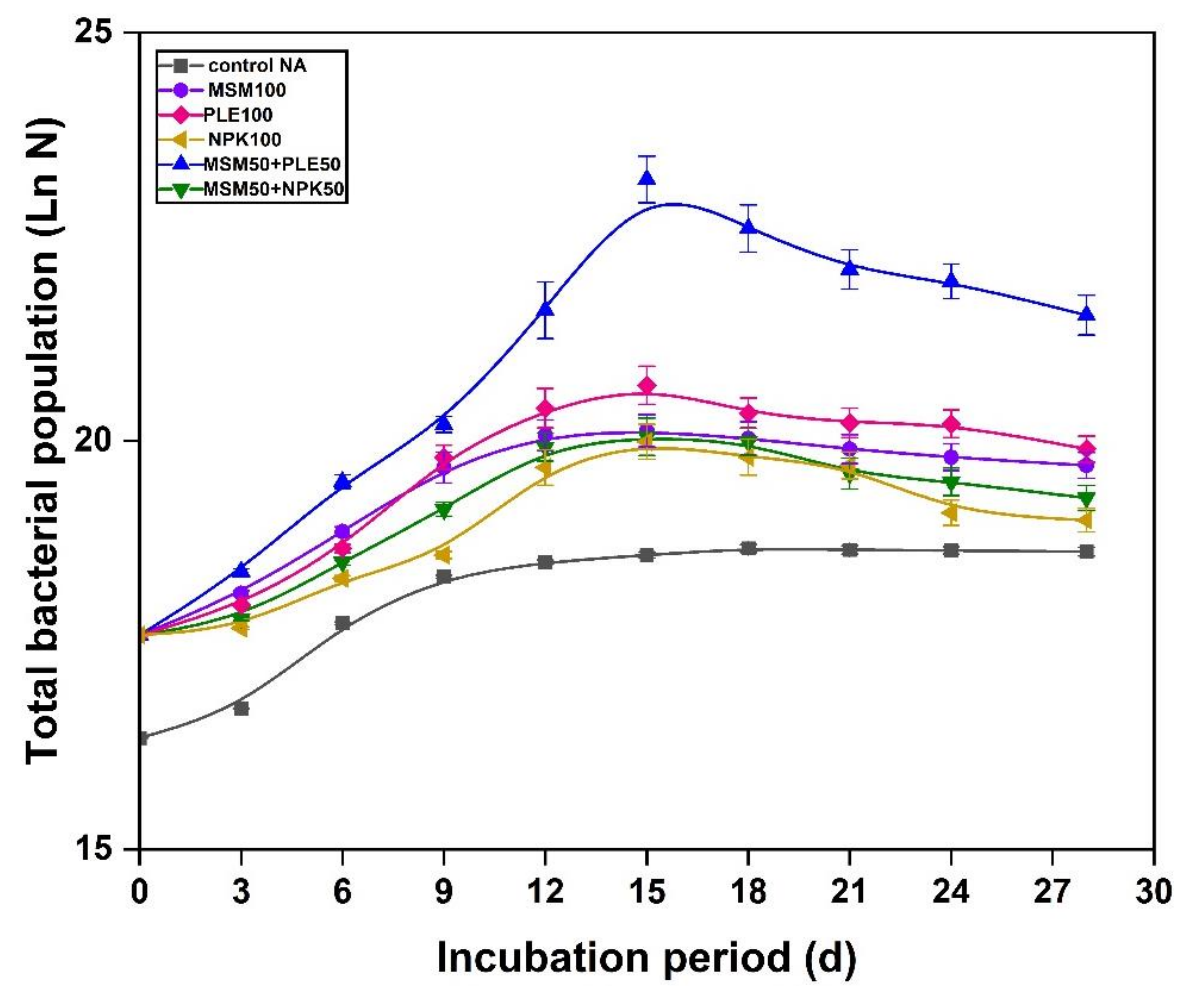


Figure 2

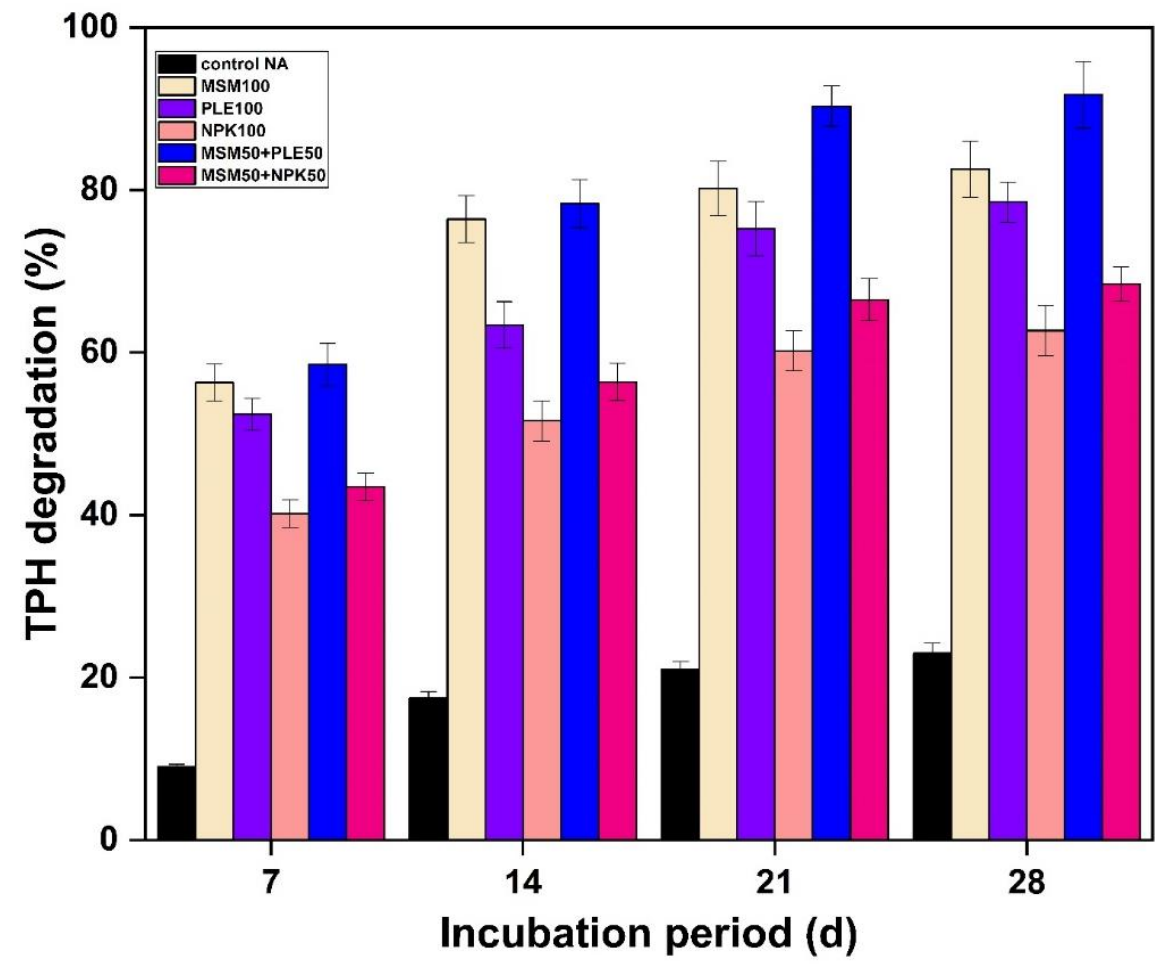

450

451

452

453

454

455

456

457

458

459 
461

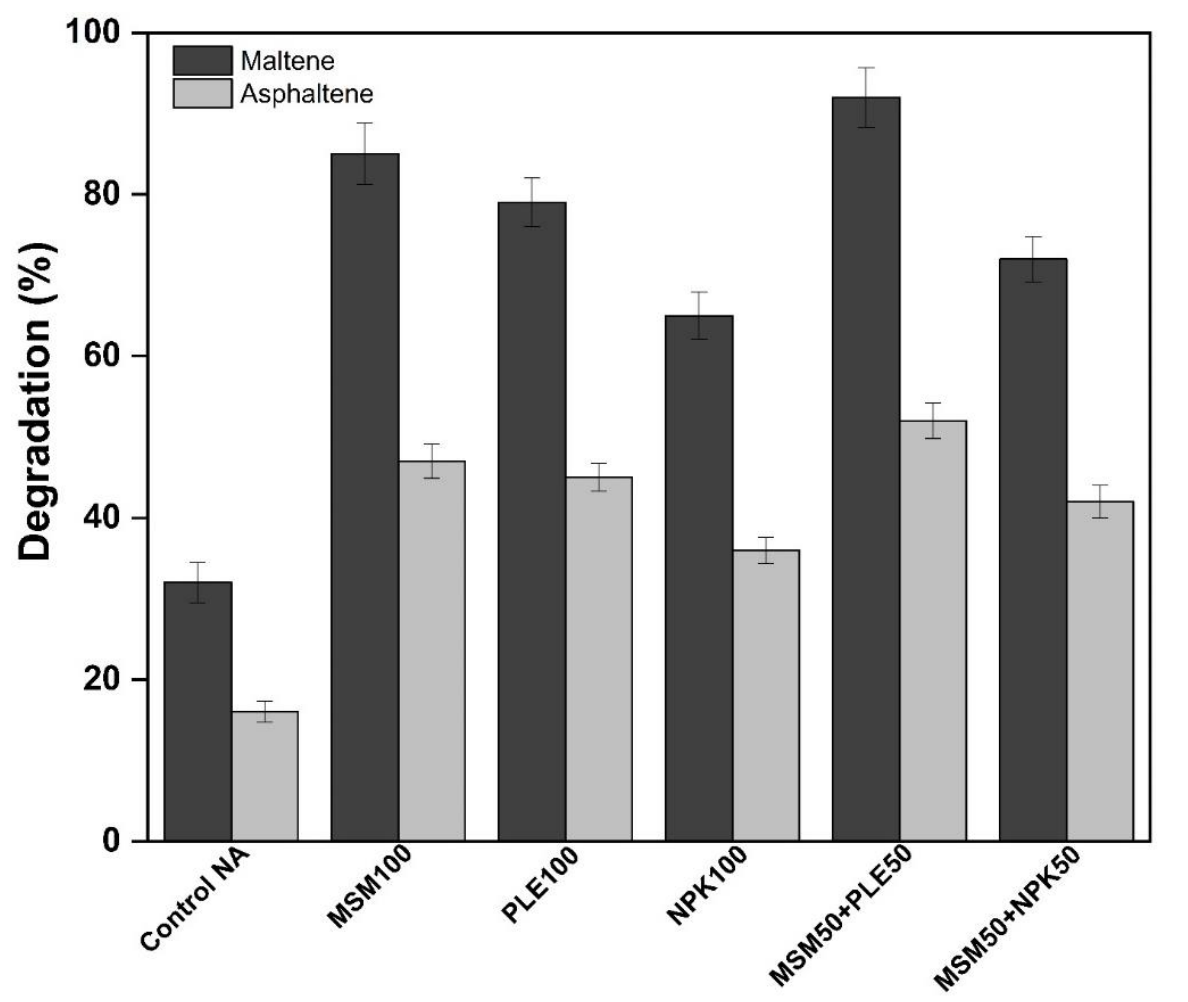

462

Different biostimulation strategies

463

464

465

466

467

468

469

470

471 


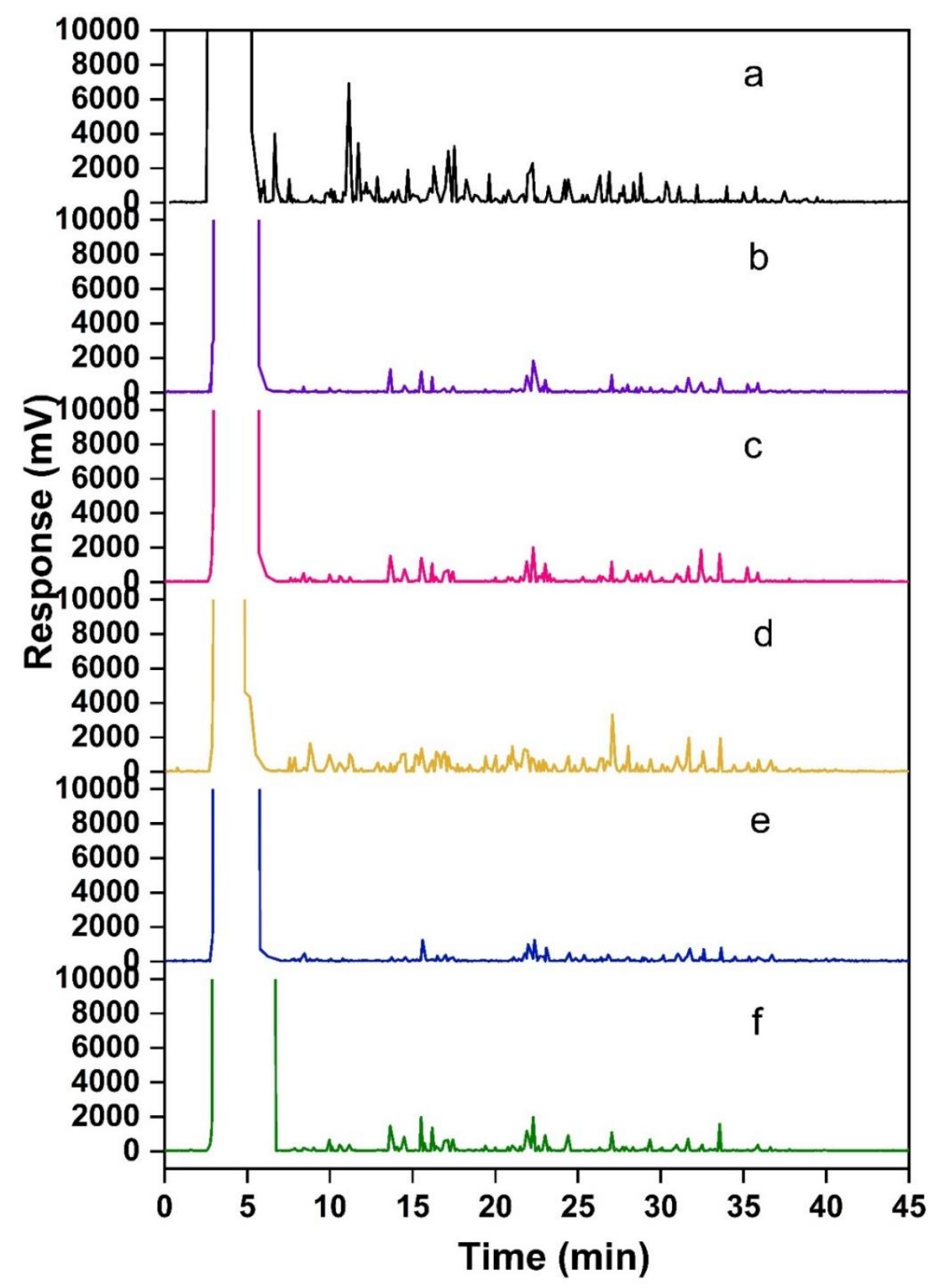




\section{Supplementary Files}

This is a list of supplementary files associated with this preprint. Click to download.

- Supplementarymaterials.docx 